\section{International Scientific Journal Theoretical \& Applied Science}

p-ISSN: 2308-4944 (print) e-ISSN: 2409-0085 (online)

Year: $2017 \quad$ Issue: $07 \quad$ Volume: 51

Published: 11.07.2017 http://T-Science.org
Denis Chemezov

Master of Engineering and Technology, Corresponding

Member of International Academy of Theoretical and Applied Sciences, Lecturer of Vladimir Industrial College, Russian Federation chemezov-da@yandex.ru

SECTION 6. Metallurgy and energy.

\title{
THE DEGREE OF SHRINKAGE POROSITY IN THE CASTINGS AFTER SOLIDIFICATION
}

Abstract: The calculated three-dimensional fields of shrinkage porosity in the castings, which was manufactured from alloy steel, carbon steel, corrosion-resistant steel, grey cast iron, malleable cast iron, without tin bronze, leaded brass, aluminium foundry alloy and zinc alloy are presented in the article.

Key words: shrinkage porosity, solidification, a casting, the Niyama criterion.

Language: English

Citation: Chemezov D (2017) THE DEGREE OF SHRINKAGE POROSITY IN THE CASTINGS AFTER SOLIDIFICATION. ISJ Theoretical \& Applied Science, 07 (51): 1-6.

Soi: http://s-o-i.org/1.1/TAS-07-51-1 Doi: crossef https://dx.doi.org/10.15863/TAS.2017.07.51.1

\section{Introduction}

The cooling process (solidification) of the castings is accompanied by the occurrence of shrinkage phenomena in the material. Shrinkage cavities, porosity, cracks and other defects (mainly hidden) of the material reduce mechanical and operational properties of the casting. Shrinkage porosity appears in the form of small pores in the casting material. The formation of shrinkage porosity in higher degree is observed in the massive solid castings. To prediction of shrinkage porosity in the casting it is used the Niyama criterion, which is defined for the each material when the calculated cooling rate of the casting $[1 ; 2 ; 3 ; 4]$.

The degree of shrinkage porosity after casting more efficient to research in the ingots of the circular cross section, made from various metal alloys.

\section{Materials and methods}

Nine solid models of the castings (ingots of the circular cross section) with assigned physical, mechanical and casting properties were exposed filling by metal melts and subsequent cooling (solidification) in the computer program LVMFlow [5]. As materials of the castings there were taken steels (G21Mn5, SS1505, 321), cast irons (EN-GJL350, EN-GJS-500) and non-ferrous alloys (CC330G, C85700, AISi12, ZA-27).

The critical points of the cooling curves of alloys [6; 7]:
1. The liquidus temperature $\left(T_{\text {liq. }}\right)$ is 1504.268 ${ }^{\circ} \mathrm{C}$, the solidus temperature $\left(T_{\text {sol. }}\right)$ is $1459.178{ }^{\circ} \mathrm{C}$, kinetic solidus is $1447.591{ }^{\circ} \mathrm{C}$ (alloy steel G21Mn5);

2. $T_{\text {liq. }}$ is $1510.09{ }^{\circ} \mathrm{C}, T_{\text {sol. }}$ is $1464.066{ }^{\circ} \mathrm{C}$, kinetic solidus is $1448.759^{\circ} \mathrm{C}$ (carbon steel SS1505);

3. $T_{\text {liq. }}$ is $1447.05{ }^{\circ} \mathrm{C}, T_{\text {sol. }}$ is $1388.766{ }^{\circ} \mathrm{C}$, kinetic solidus is $1375.477{ }^{\circ} \mathrm{C}$ (corrosion-resistant steel 321);

4. $T_{\text {liq. }}$ is $1244.538{ }^{\circ} \mathrm{C}, T_{\text {sol. }}$ is $1151.78{ }^{\circ} \mathrm{C}$, kinetic solidus is $1136.965{ }^{\circ} \mathrm{C}$ (grey cast iron $\mathrm{EN}$ GJL-350);

5. $T_{\text {liq. }}$ is $1196.409{ }^{\circ} \mathrm{C}, T_{\text {sol. }}$ is $1149.46{ }^{\circ} \mathrm{C}$, kinetic solidus is $1134.511{ }^{\circ} \mathrm{C}$ (malleable cast iron EN-GJS-500);

6. $T_{\text {liq. }}$ is $1039.539{ }^{\circ} \mathrm{C}, T_{\text {sol. }}$ is $1037{ }^{\circ} \mathrm{C}$, kinetic solidus is $1022.011^{\circ} \mathrm{C}$ (without tin bronze CC330G);

7. $T_{\text {liq. }}$ is $919.553{ }^{\circ} \mathrm{C}, T_{\text {sol. }}$ is $902{ }^{\circ} \mathrm{C}$, kinetic solidus is $901.245^{\circ} \mathrm{C}$ (leaded brass C85700);

8. $T_{\text {liq. }}$ is $598.974{ }^{\circ} \mathrm{C}, T_{\text {sol. }}$ is $576.323{ }^{\circ} \mathrm{C}$, kinetic solidus is $561.322{ }^{\circ} \mathrm{C}$ (aluminium foundry alloy AISi12);

9. $T_{\text {liq. }}$ is $489.378^{\circ} \mathrm{C}, T_{\text {sol. }}$ is $377.686^{\circ} \mathrm{C}$, kinetic solidus is $362.777^{\circ} \mathrm{C}$ (zinc alloy ZA-27).

The chemical composition of each alloy, the initial temperatures of melts, the simulation parameters of the casting process and the calculated values of shrinkage of the castings are given in the work [8].

\section{Results and discussion}

The simulation results were processed in modules of the program LVMFlow. 


\begin{tabular}{|c|c|c|c|c|c|c|}
\hline Impact Factor: & $\begin{array}{l}\text { ISRA (India) } \\
\text { ISI (Dubai, UAF } \\
\text { GIF (Australia) } \\
\text { JIF }\end{array}$ & $\begin{array}{l}=1.344 \\
=0.829 \\
=0.564 \\
=1.500\end{array}$ & $\begin{array}{l}\text { SIS (USA) } \\
\text { PИНЦ (Russia) } \\
\text { ESJI (KZ) } \\
\text { SJIF (Morocco) }\end{array}$ & $\begin{array}{l}=0.912 \\
=0.234 \\
=\mathbf{3 . 8 6 0} \\
=\mathbf{2 . 0 3 1}\end{array}$ & $\begin{array}{l}\text { ICV (Poland) } \\
\text { PIF (India) } \\
\text { IBI (India) }\end{array}$ & $\begin{array}{l}=6.630 \\
=1.940 \\
=4.260\end{array}$ \\
\hline
\end{tabular}

The dependencies of shrinkage and the Niyama criterion for alloy steel G21Mn5, carbon steel SS1505, corrosion-resistant steel 321, grey cast iron EN-GJL-350, malleable cast iron EN-GJS-500, without tin bronze CC330G, leaded brass C85700, aluminium foundry alloy AISi12 and zinc alloy ZA27 from the cooling rate of the casting are presented in Fig. $1-9$. The yellow line on charts is the dependence of the liquid phase of alloys during cooling of the castings. The least cooling rate in all phases was defined for the casting from alloy steel G21Mn5. The maximum cooling rate is observed on the first and last seconds of the solidification process of the castings. The value of shrinkage for grey and malleable cast irons changes only in the liquid state. Towards to the end of the crystallization process of the iron castings, the value of shrinkage practically doesn't change. For all other alloys, shrinkage increases on all the time range of the cooling process. With increasing linear shrinkage of the casting, the value of the Niyama criterion decreases.

The volumes of the castings with the highest degree of the formation of shrinkage porosity are presented in Fig. 10. For grey and malleable cast irons, porosity is formed in the small volume, located in the center of the casting. In the castings from alloy and carbon steels, shrinkage porosity is formed in the larger volume in comparison to the cast iron castings. In the casting from corrosion-resistant steel after solidification, shrinkage porosity is observed in approximately $60 \%$ of the volume. Equal volumes, subjected by shrinkage porosity, are calculated for the castings, made from without tin bronze and aluminium foundry alloy.

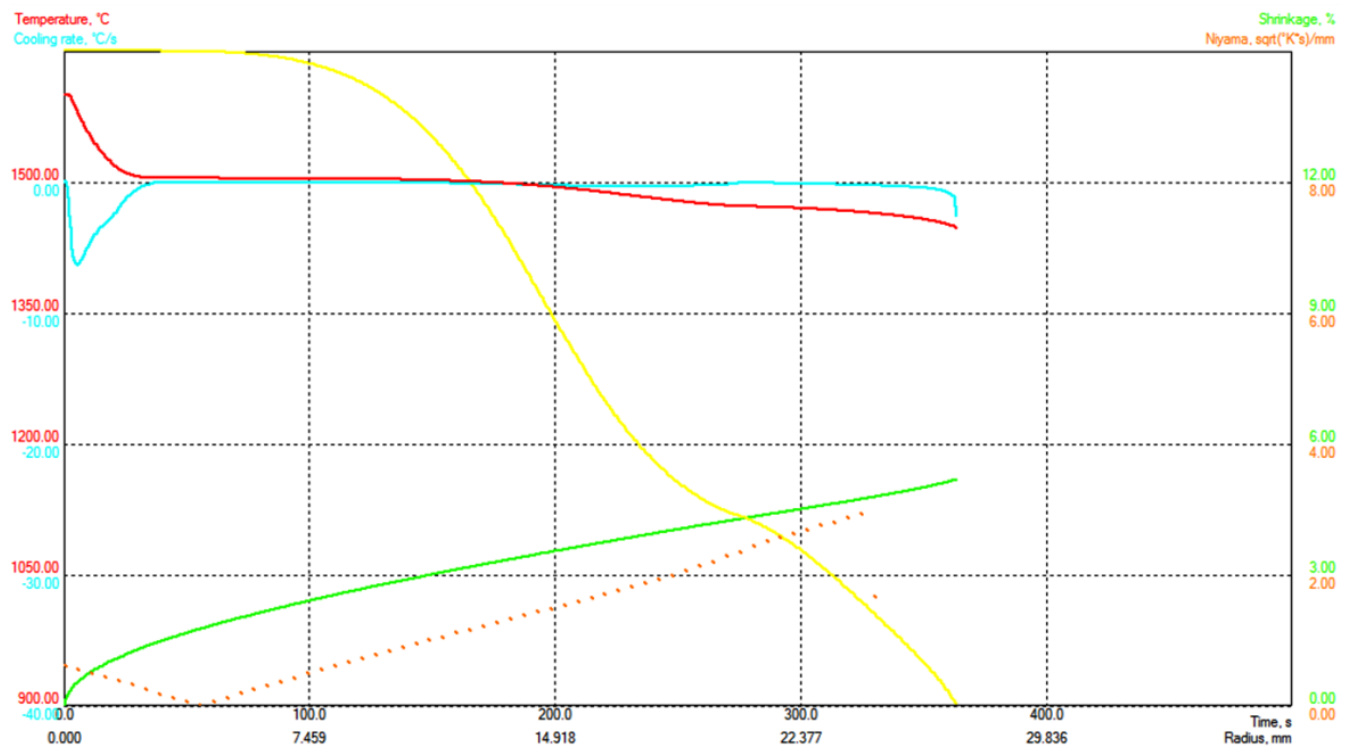

Figure 1 - Shrinkage and the Niyama criterion for the casting from alloy G21Mn5 during cooling.

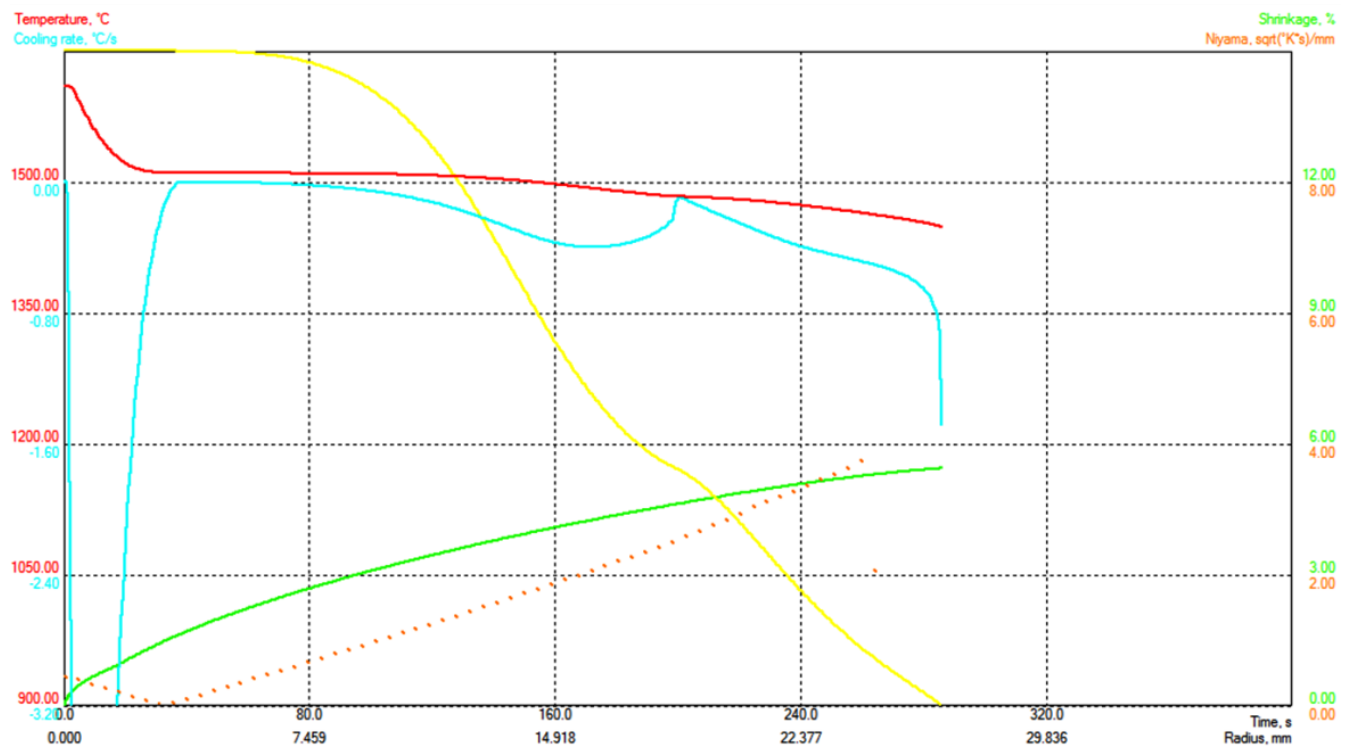

Figure 2 - Shrinkage and the Niyama criterion for the casting from alloy SS1505 during cooling. 


\begin{tabular}{l|lr|ll|ll} 
& ISRA (India) & $=\mathbf{1 . 3 4 4}$ & SIS (USA) & $=\mathbf{0 . 9 1 2}$ & ICV (Poland) & $=\mathbf{6 . 6 3 0}$ \\
Impact Factor: & ISI (Dubai, UAE) $=\mathbf{0 . 8 2 9}$ & PUHI (Russia) & $=\mathbf{0 . 2 3 4}$ & PIF (India) & $=\mathbf{1 . 9 4 0}$ \\
& GIF (Australia) & $=\mathbf{0 . 5 6 4}$ & ESJI (KZ) & $=\mathbf{3 . 8 6 0}$ & IBI (India) & $\mathbf{4 . 2 6 0}$ \\
& JIF & $\mathbf{1 . 5 0 0}$ & SJIF (Morocco) & $\mathbf{2 . 0 3 1}$ & & \\
\hline
\end{tabular}

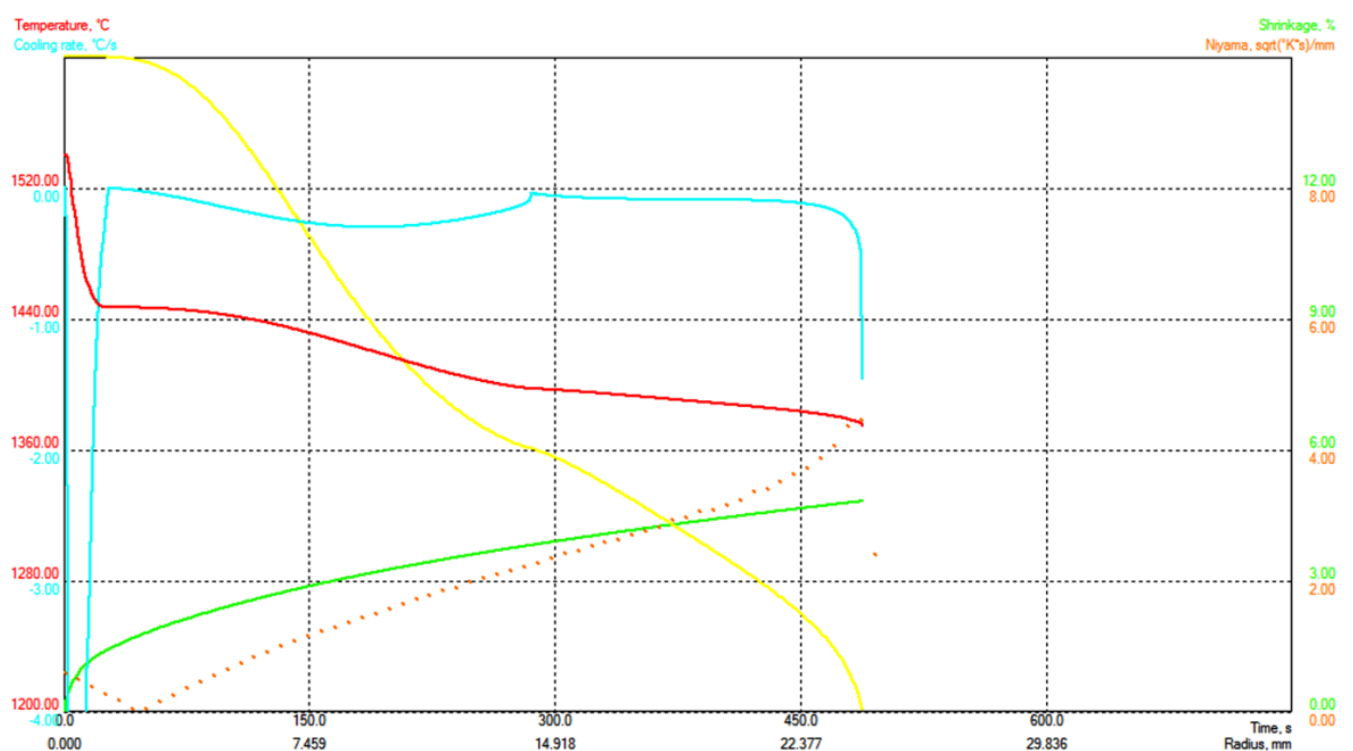

Figure 3 - Shrinkage and the Niyama criterion for the casting from alloy 321 during cooling.

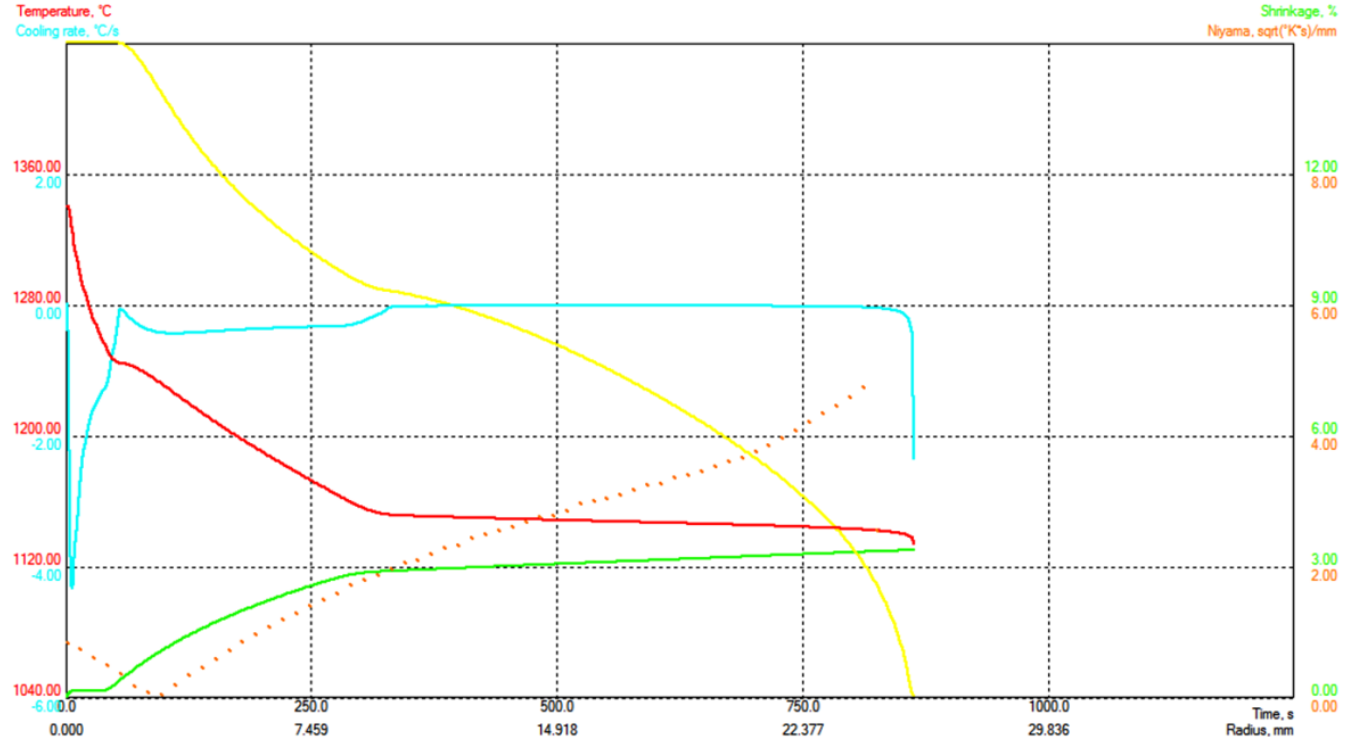

Figure 4 - Shrinkage and the Niyama criterion for the casting from alloy EN-GJL-350 during cooling.

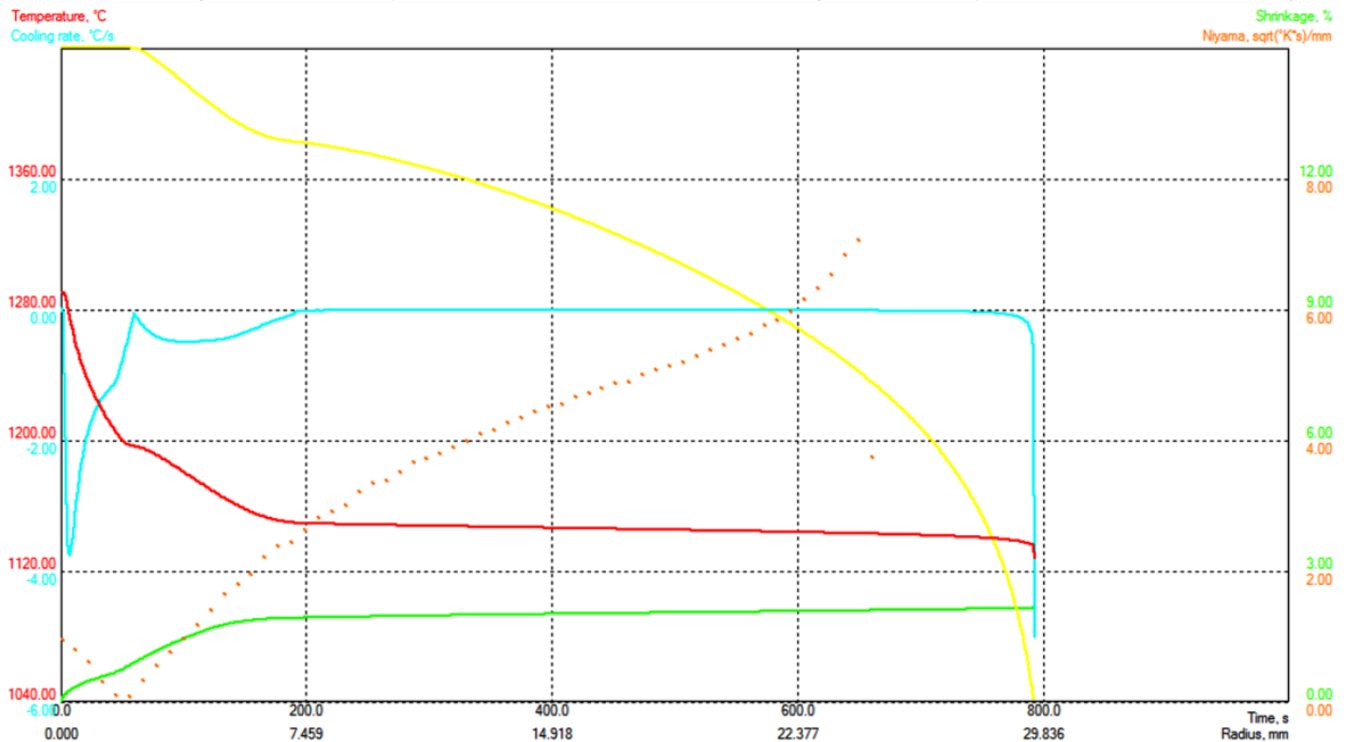

Figure 5 - Shrinkage and the Niyama criterion for the casting from alloy EN-GJS-500 during cooling.

ISPC Materials and technologies, 


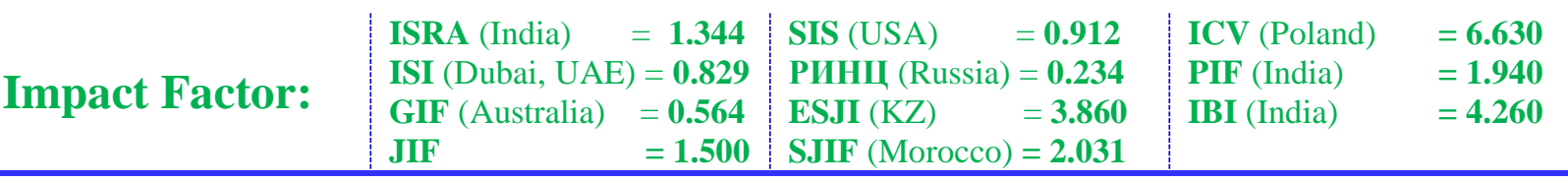

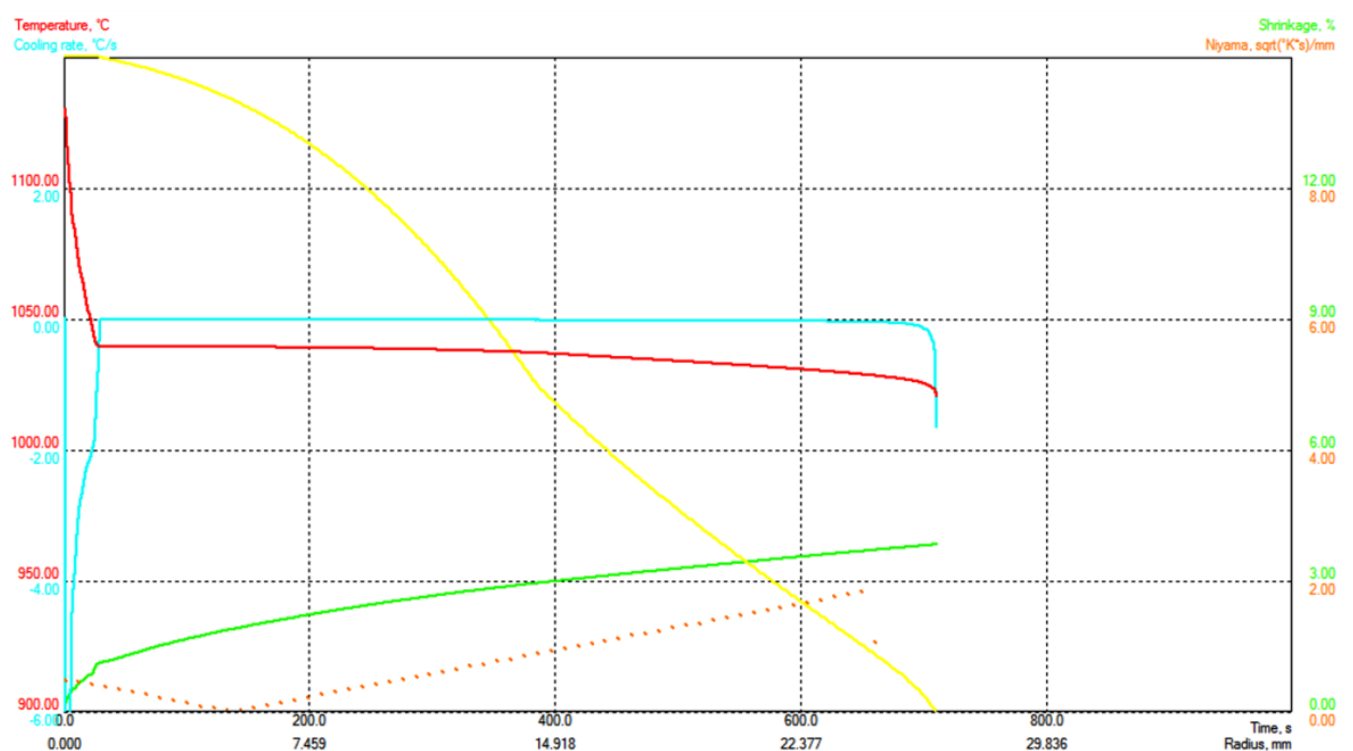

Figure 6 - Shrinkage and the Niyama criterion for the casting from alloy CC330G during cooling.

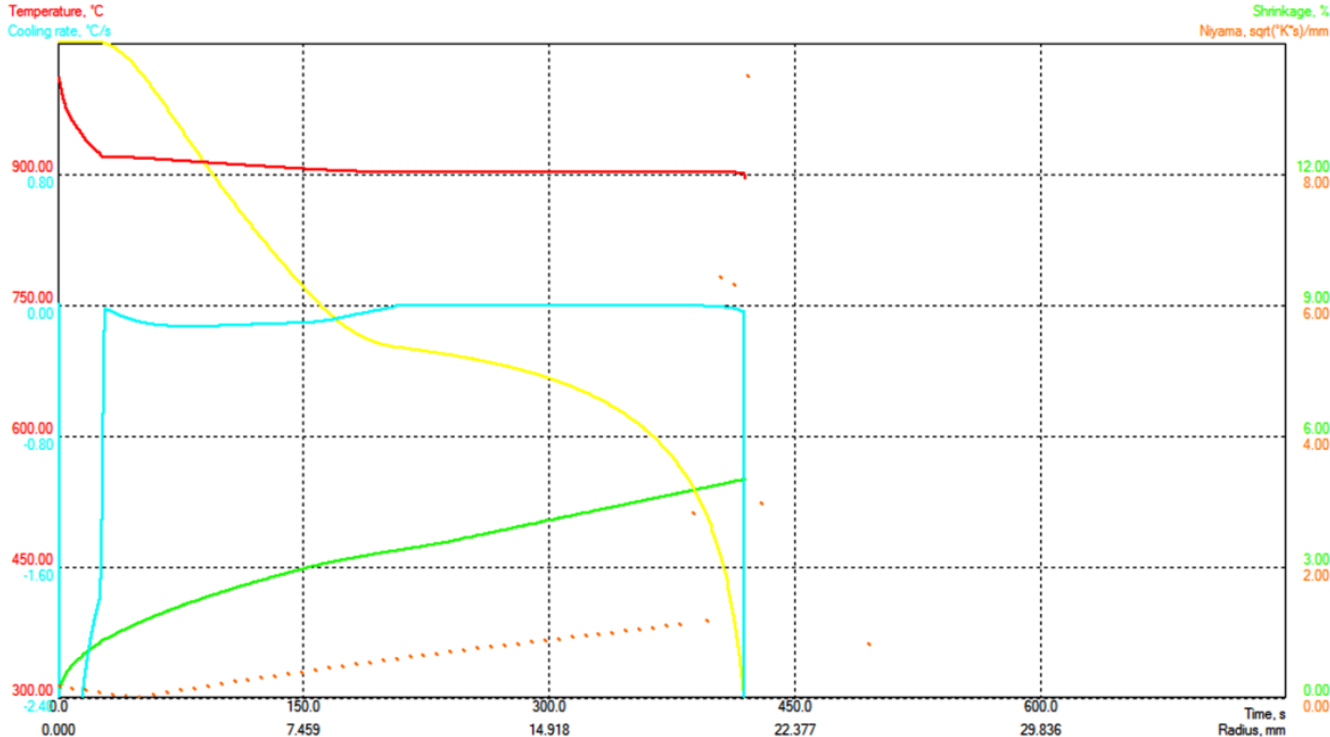

Figure 7 - Shrinkage and the Niyama criterion for the casting from alloy $\mathbf{C 8 5 7 0 0}$ during cooling.

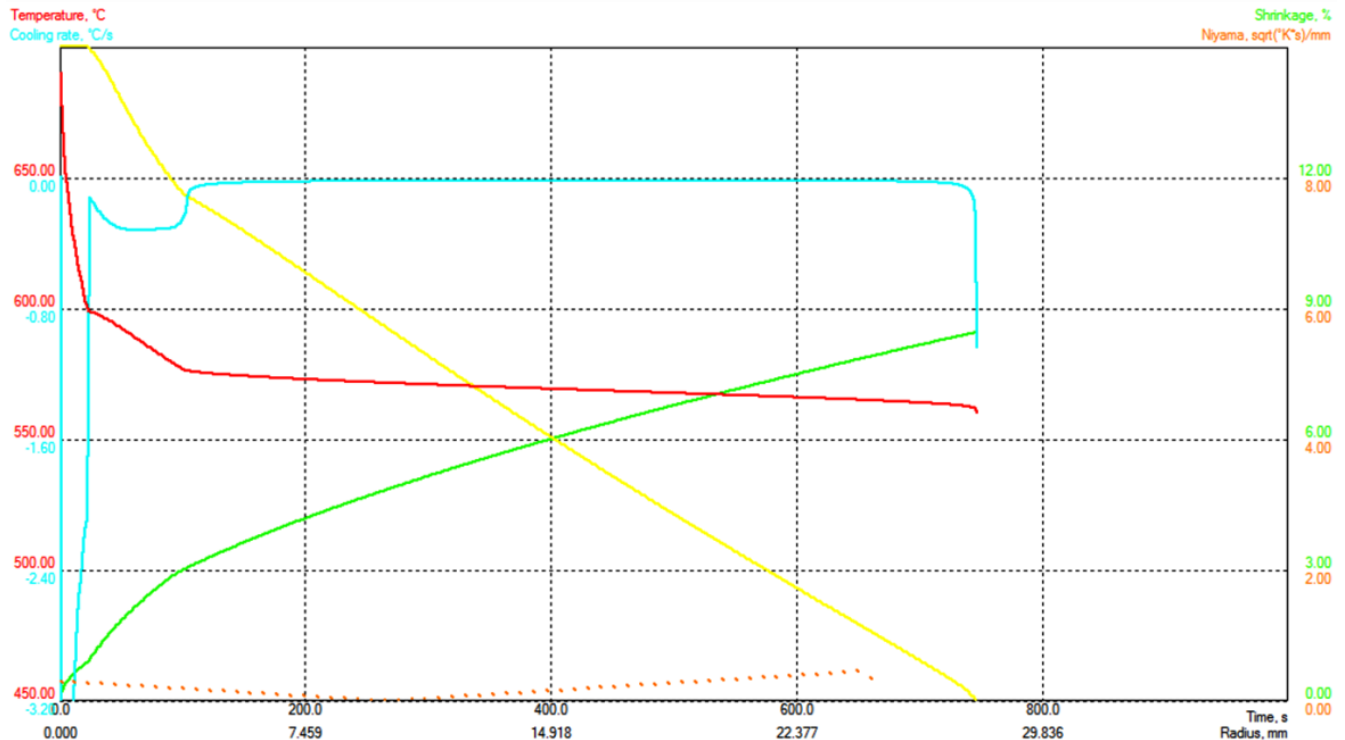

Figure 8 - Shrinkage and the Niyama criterion for the casting from alloy AISi12 during cooling.

ISPC Materials and technologies, 


\begin{tabular}{l|lrl|l|ll} 
& ISRA (India) & $=\mathbf{1 . 3 4 4}$ & SIS (USA) & $=\mathbf{0 . 9 1 2}$ & ICV (Poland) & $=\mathbf{6 . 6 3 0}$ \\
Impact Factor: & ISI (Dubai, UAE) $=\mathbf{0 . 8 2 9}$ & PUHU (Russia) $=\mathbf{0 . 2 3 4}$ & PIF (India) & $=\mathbf{1 . 9 4 0}$ \\
& GIF (Australia) & $\mathbf{0 . 5 6 4}$ & ESJI (KZ) & $=\mathbf{3 . 8 6 0}$ & IBI (India) & $\mathbf{4 . 2 6 0}$
\end{tabular}

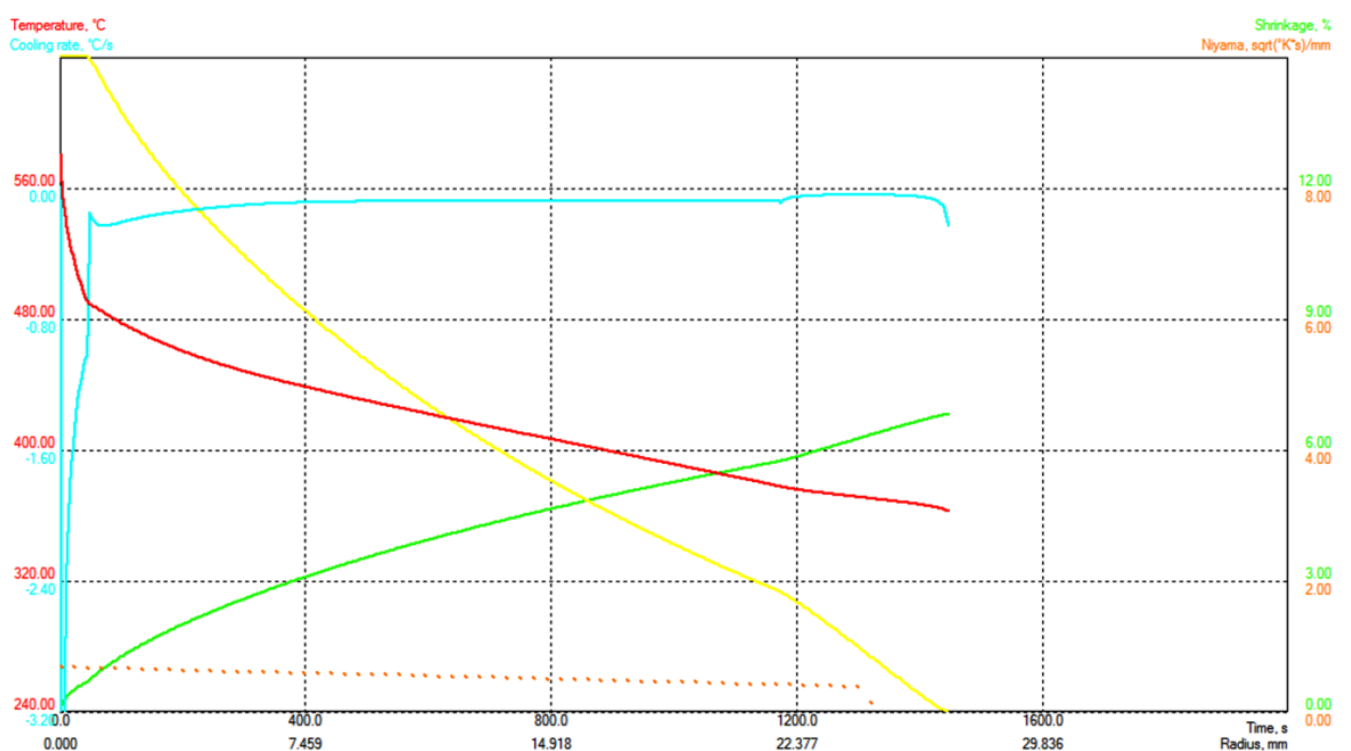

Figure 9 - Shrinkage and the Niyama criterion for the casting from alloy ZA-27 during cooling.

Herewith the calculated value of linear shrinkage of the casting from alloy AISi12 is maximum of all considered alloys. For non-ferrous alloys C85700 and ZA-27 shrinkage porosity prevails in almost in the entire volume of the castings. The volume of alloy, located above of the end surface of the casting is alloy remaining in the feeder (Fig. 10, C).

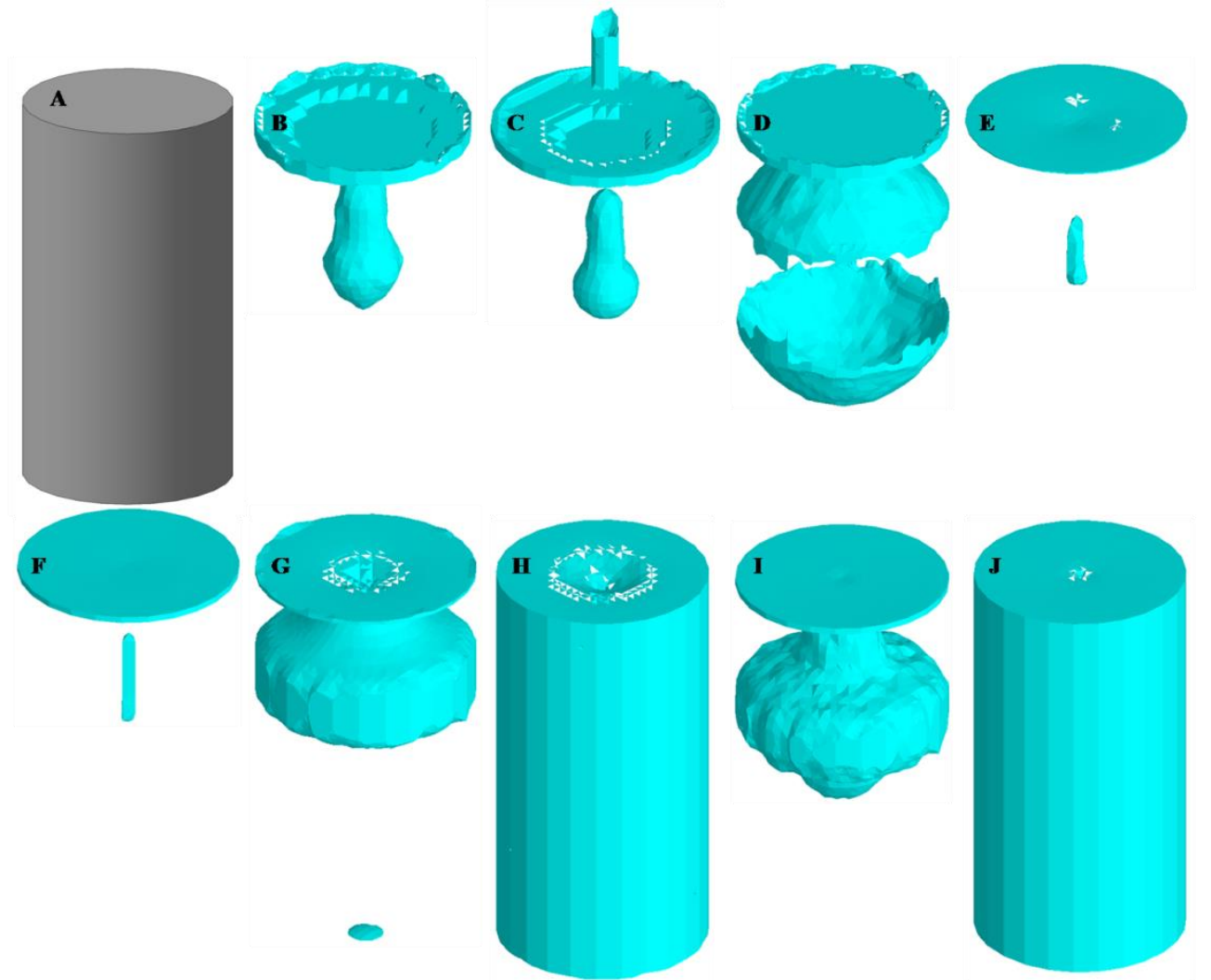

Figure 10 - The volumes of the castings with the highest degree of the formation of shrinkage porosity: A the solid model of the casting, B - alloy steel G21Mn5, C - carbon steel SS1505, D - corrosion-resistant steel 321, E - grey cast iron EN-GJL-350, F - malleable cast iron with nodular graphite EN-GJS-500, G - without tin bronze CC330G, H - leaded brass C85700, I - aluminium foundry alloy AISi12, J - zinc alloy ZA-27. 


\begin{tabular}{|c|c|c|c|c|c|c|}
\hline Impact Factor: & $\begin{array}{l}\text { ISRA (India) } \\
\text { ISI (Dubai, UAF } \\
\text { GIF (Australia) } \\
\text { JIF }\end{array}$ & $\begin{array}{l}=1.344 \\
=0.829 \\
=0.564 \\
=1.500\end{array}$ & $\begin{array}{l}\text { SIS (USA) } \\
\text { PИНЦ (Russia) } \\
\text { ESJI (KZ) } \\
\text { SJIF (Morocco) }\end{array}$ & $\begin{array}{l}=0.912 \\
=0.234 \\
=3.860 \\
=\mathbf{2 . 0 3 1}\end{array}$ & $\begin{array}{l}\text { ICV (Poland) } \\
\text { PIF (India) } \\
\text { IBI (India) }\end{array}$ & $\begin{array}{l}=6.630 \\
=1.940 \\
=4.260\end{array}$ \\
\hline
\end{tabular}

The calculated minimum values of the Niyama criterion when which shrinkage porosity is not observed in materials of the castings are presented in table 1 . The table shows, each group of alloys has the certain value of the Niyama criterion. The value of the Niyama criterion for zinc alloy ZA-27 is theoretical. In practice there are accepted values of the criterion from 0.9 to 1 .

Table 1

The minimum value of the Niyama criterion when which shrinkage porosity is not observed in the casting material.

\begin{tabular}{|c|c|}
\hline The name of alloy & The Niyama criterion, $\left(\sqrt{{ }^{\circ} K \times s}\right) / \mathrm{mm}$ \\
\hline G21Mn5 & \multirow{3}{*}{2.2} \\
\hline SS1505 & \\
\hline 321 & \\
\hline EN-GJL-350 & \multirow{2}{*}{1.8} \\
\hline EN-GJS-500 & \\
\hline CC330G & \multirow{2}{*}{2.8} \\
\hline $\mathrm{C} 85700$ & \\
\hline AISi12 & 0.8 \\
\hline ZA-27 & 3.0 \\
\hline
\end{tabular}

\section{Conclusion}

Quality of the castings is expressed by the minimal formation of shrinkage porosity in the material. To a greater degree this quality correspond the castings, made from grey and malleable cast irons. To a lesser degree this quality correspond the castings, made from corrosion-resistant steel 321, leaded brass C85700 and zinc alloy ZA-27. Results of the computer simulation will be useful for the prediction of shrinkage porosity in the castings, obtained by gravity casting.

\section{References:}

1. Korotchenko AY (2010) Criterias of shrinkage formation in castings. Russian foundry man, №4. - pp. 43 - 47.

2. Sigworth GK, Wang C (1993) Mechanisms of Porosity Formation during Solidification: A Theoretical Analysis, Met. Transactions B, Vol. 24B. - pp. 349 - 364 .

3. (2017) Casting defect. Available: https://en.wikipedia.org/wiki/Casting defect (Accessed: 01.07.2017).

4. Chvorinov N (1940) Theory of the Solidification of Castings. Geisserei, 27. - pp. $177-225$.

5. Chemezov D (2017) Stress fields in a steel casting. ISJ Theoretical \& Applied Science, 05
(49): 165 - 172. Soi: http://s-o-i.org/1.1/TAS05-49-25 Doi: https://dx.doi.org/10.15863/TAS.2017.05.49.25

6. (2017) Cooling curve. Available: https://en.wikipedia.org/wiki/Cooling curve (Accessed: 01.07.2017).

7. (2017) Interpretation of cooling curves. Available:

https://www.doitpoms.ac.uk/tlplib/CD4/cooling .php (Accessed: 01.07.2017).

8. Chemezov D (2017) Shrinkage of some metal alloys after solidification. ISJ Theoretical \& Applied Science, 06 (50): 87 - 89. Soi: http://so-i.org/1.1/TAS-06-50-10 Doi: https://dx.doi.org/10.15863/TAS.2017.06.50.10 